\title{
Peningkatan Perilaku Kesehatan Masyarakat terhadap Bahaya ISPA di Wilayah Puskesmas Alalak Tengah
}

\author{
Mahmudah $^{1}$, Yeni Riza ${ }^{2}$, M. Bahrul Ilmi ${ }^{3}$ \\ ${ }^{1,2,3}$ Fakultas Kesehatan Masyarakat Universitas Islam Kalimantan MAB Banjarmasin \\ Email: mahmudah936@gmail.com
}

\begin{abstract}
ISPA is a disease that often occurs with the arrival of the dry season and increasing forest and land fires. Various attempts were made to control ISPA, one of which was handling respiratory problems due to smog. In Puskesmas Alalak Tengah, ISPA is the first of 10 diseases in the last 2 years. In addition, some people still consider trivial diseases of ISPA and are not accustomed to wearing masks when doing activities and activities. Therefore, community service needs to be held to increase community awareness of ISPA. The aim of the activity is to increase public health knowledge and behavior towards the danger of ISPA. The target activity is the people in Alalak Tengah Village through counseling using leaflet and poster media. After being educated through counseling and evaluating the participants, an increase in public health behavior towards the danger of ISPA it appears from the motivation and enthusiasm of the participants to use masks, so that they are more aware of the risk of ISPA transmission.
\end{abstract}

Keywords: ISPA, smog, forest and land fires, mask

ISPA merupakan penyakit yang sering terjadi seiring tibanya musim kemarau dan meningkatnya kebakaran hutan dan lahan. Berbagai upaya dilakukan untuk pengendalian ISPA, salah satunya penanganan pada gangguan pernapasan akibat kabut asap. Di Puskesmas Alalak Tengah, ISPA menjadi urutan pertama dari 10 penyakit terbanyak selama 2 tahun terakhir. Selain itu juga sebagian masyarakat masih menganggap sepele penyakit ISPA dan belum terbiasa untuk menggunakan masker pada saat melakukan kegiatan dan aktifitas. Oleh karena itu, perlu diadakan pengabdian masyarakat untuk meningkatkan kewaspadaan masyarakat terhadap ISPA. Tujuan kegiatan adalah untuk meningkatkan pengetahuan dan perilaku kesehatan masyarakat terhadap bahaya ISPA. Sasaran kegiatan adalah masyarakat di Kelurahan Alalak Tengah melalui penyuluhan dengan menggunakan media leaflet dan poster. Setelah diberikan edukasi melalui penyuluhan dan dilakukan evaluasi pada peserta diperoleh peningkatan perilaku kesehatan masyarakat terhadap bahaya ISPA, hal ini dilihat dari motivasi dan antusiasme para peserta untuk menggunakan masker, sehingga mereka lebih waspada terhadap resiko penularan ISPA.

Kata Kunci: ISPA, masker, kabut asap, kebakaran hutan dan lahan

\section{PENDAHULUAN}

Keberhasilan pembangunan kesehatan di Indonesia salah satunya ditunjukan dalam menurunkan angka kesakitan dari berbagai penyakit menular. Namun demikian, Indonesia masih dihadapkan dengan berbagai tantangan dalam pencegahan dan pengendalian penyakit menular, antara lain masih tingginya angka kesakitan dan kematian akibat infeksi saluran pernapasan akut (ISPA). (Kemenkes RI, 2017)
Direktur Jenderal Pencegahan dan Pengendalian Penyakit Kementian Kesehatan (Kemenkes), Anung Sugihantono mengatakan bahwa terjadi peningkatan cukup signifikan pada penyakit ISPA di beberapa daerah di Indonesia. Salah satu faktor yang mempengaruhi yakni musim kemarau yang terjadi (Abdi, 2019). Seiring dengan tibanya musim kemarau, wilayah Indonesia masih banyak lahan hutan yang rawan menjadi sumber terjadinya kebakaran. Berbagai upaya 
dilakukan untuk pengendalian ISPA, salah satunya difokuskan pada penanganan gangguan pernapasan akibat kabut asap.

Kabut asap dari karhutla mengandung bahan-bahan yang dapat menimbulkan berbagai dampak dan masalah kesehatan. Dampak tersebut bisa berupa iritasi mata, iritasi kulit dan peradangan saluran pernapasan yang bisa berlanjut menjadi infeksi saluran pernapasan dan lain-lain. Walaupun ISPA disebabkan oleh virus, namun paparan intens dari kabut asap menyebabkan melemahnya kemampuan saluran pernapasan dan paru melawan infeksi sehingga meningkatkan risiko terjadinya ISPA (Suni, 2019)

Beberapa cara yang dapat dilakukan untuk melindungi diri dari ISPA diantaranya: 1) upayakan untuk tetap berada dalam rumah; 2) gunakan masker bila harus keluar rumah; 3) minum air putih yang banyak; 4) hindari aktifitas terlalu berat; 5) terapkan PHBS serta 6) segersa ke fasilitas pelayanan Kesehatan bila ada keluhan sakit (Rokom, 2016)

Sementara itu, Badan Nasional Penanggulangan Bencana (BNPB) dan Kementerian Kesehatan per 16 September 2019 pukul 16.00 WIB mencatat setidaknya 144.219 ribu masyarakat di Sumatera dan Kalimantan terkena ISPA (Kembaren, 2019). Mengutip data Badan Penanggulangan Bencana Daerah (BPBD) Kalimantan Selatan, ratusan kasus ISPA juga menimpa masyarakat di Banjarmasin. tercatat kasus ISPA di Banjarmasin periode 1 Januari - akhir Agustus 2019 sebanyak 771 kasus. Bahkan pada periode $1-19$ September 2019, kasus ISPA akibat kabut asap di Banjarmasin sebanyak 110 kasus (Anonymous, 2019)

Penyakit ISPA menjadi urutan ketiga dari 10 penyakit terbanyak di Banjarmasin (Banjarmasin Post, 2019). Di Puskesmas Alalak Tengah, ISPA menjadi urutan pertama dari 10 penyakit terbanyak selama 2 tahun terakhir. Data 8 bulan terakhir (Januari 2019-Agustus 2019) tercatat sebanyak 1.747 kunjungan karena ISPA (Puskesmas Alalak, 2019).

Berdasarkan hal tersebut, sosialisasi tentang bahaya penyakit ISPA perlu dilakukan karena sebagian masyarakat masih menganggap sepele penyakit ISPA dan belum terbiasa menggunakan masker pada saat melakukan kegiatan dan aktifitas sehari-hari. Oleh karena itu juga diperlukan tindakan pencegahan seperti pembagian masker untuk dapat mendukung perilaku kesehatan masyarakat agar terhindar dari penyakit ISPA.

\section{TARGET DAN LUARAN}

Khalayak sasaran dari mitra pengabdian adalah warga masyarakat yang berdomisili di Kelurahan Alalak Tengah. Luaran yang diharapkan dari kegiatan ini antara lain:

1. Meningkatnya pengetahuan masyarakat tentang bahaya penyakit ispa

2. Meningkatnya pengetahuan masyarakat tentang tata cara penggunaan masker yang benar

3. Meningkatnya perilaku penggunaan masker sebagai salah satu pencegahan penyakit ispa.

\section{METODE PELAKSANAAN}

Kegiatan dilaksanakan pada Bulan Januari 2020 bersamaan dengan pelaksanaan kegiatan Posbindu. Kegiatan didampingi oleh 4 petugas Posbindu dari Puskesmas, kader posbindu dan dihadiri oleh 26 warga. Kegiatan dibuka oleh petugas Puskesmas dan selanjutnya diberikan edukasi melalui penyuluhan.

Beberapa tahapan kegiatan dilaksanakan sebagai berkut:

1. Pembukaan oleh petugas puskesmas

2. Pembagian leaflet

3. Penyuluhan dan diskusi tentang ISPA

4. Pembagian masker serta praktik cara penggunaan masker

5. Evaluasi dan penutup. 


\section{HASIL DAN PEMBAHASAN}

Pengetahuan merupakan hasil dari tahu, dan ini terjadi setelah orang melakukan penginderaan terhadap suatu objek tertentu. Pengetahuan yang baik tentang ISPA akan membawa dampak positif bagi kesehatan. (Notoadmodjo, 2014). Pengetahuan dapat diperoleh melalui Pendidikan formal maupun non formal. Pendidikan non formal salah satunya bisa didapatkan dari kegiatan penyuluhan.

Sebelum diberikan penyuluhan, diadakan pre test kepada peserta. Hasil pre test didapatkan bahwa 13 peserta $(50 \%)$ memiliki pengetahuan kurang. Akan tetapi, pada hasil evaluasi didapatkan peningkatan yang cukup signifikan. Dari hasil post test yang dilaksanakan didapatkan sebanyak 21 peserta $(80 \%)$ memiliki pengetahuan baik. Sedangkan 6 peserta lainnya (20\%) masih memiliki pengetahuan kurang karena keterbatasan ruangan dan diantaranya ada yang membawa anak.

Selain pengetahuan tentang ispa, masyarakat juga diberikan edukasi tentang tata cara penggunaan masker yang benar. Dari pre test yang dilakukan menunjukan bahwa sebagian besar (75\%) masyarakat sudah memiliki pengetahuan yang baik tentang cara penggunaan masker. Akan tetapi hanya sekitar $57,6 \%$ (15 peserta) yang selalu menggunakan masker pada saat beraktifitas di luar rumah, baik masker kesehehatan maupun masker kain.

Masih rendahnya persentase masyarakat yang menggunakan masker disebabkan karena mereka masih belum terbiasa untuk menggunakan masker, terutama pada saat melakukan aktivitas di luar rumah.

Hal ini berarti bahwa pengetahuan yang dimiliki masyarakat tidak diaplikasikan untuk melakukan pencegahan terhadap bahaya ISPA. Sesuai dengan teori yang menyatakan bahwa pengetahuan yang dimiliki oleh seseorang apabila tidak diaplikasikan dengan baik, maka tidak akan berdampak positif bagi kesehatan (Notoadmodjo, 2007).

Dalam dekade terakhir, hampir setiap tahun terjadi kebakaran hutan dan lahan di wilayah Sumatera dan Kalimantan, sehingga berdampak langung terhadap bencana asap dan meningkatnya penderita ISPA (Pusdatin Kemenkes RI, 2015).

ISPA disebabkan oleh infeksi virus, namun paparan intens dari kabut asap dapat menyebabkan penurunan faal paru, asma, dan bronchitis dan pneumonia (Amin, 2010). ISPA sering berada pada daftar 10 penyakit terbanyak di puskesmas maupun rumah sakit. Episode batuk dan pilek pda balita di Indonesia diperkirakan 3-6 kali per tahun (Kunoli, 2013).

Salah satu tindakan pencegahan yang dapat dilakukan untuk menghindari ISPA adalah meningkatkan perilaku penggunaan masker. Masker bisa menjadi pelindung pertama dari paparan polutan, gas berbahaya, termasuk kabut asap akibat kebakaran hutan dan lahan. Masker dapat menyaring udara sebelum akhirnya masuk ke dalam saluran pernapasan.

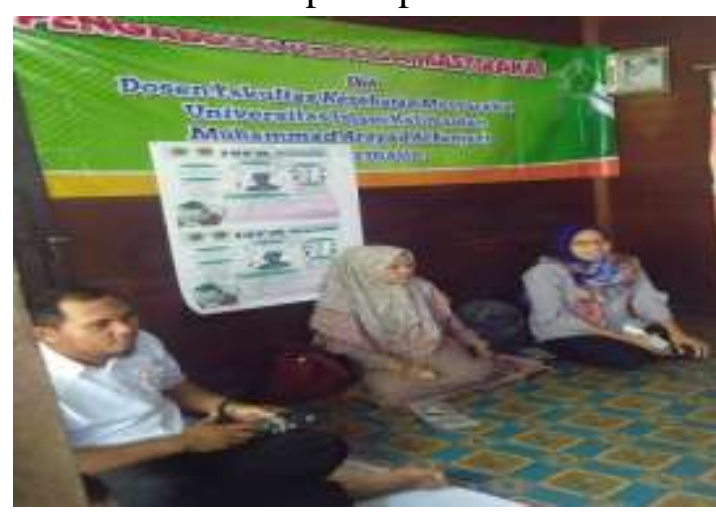

Gambar 1. Pembukaan dipimpin oleh Petugas Posbindu 


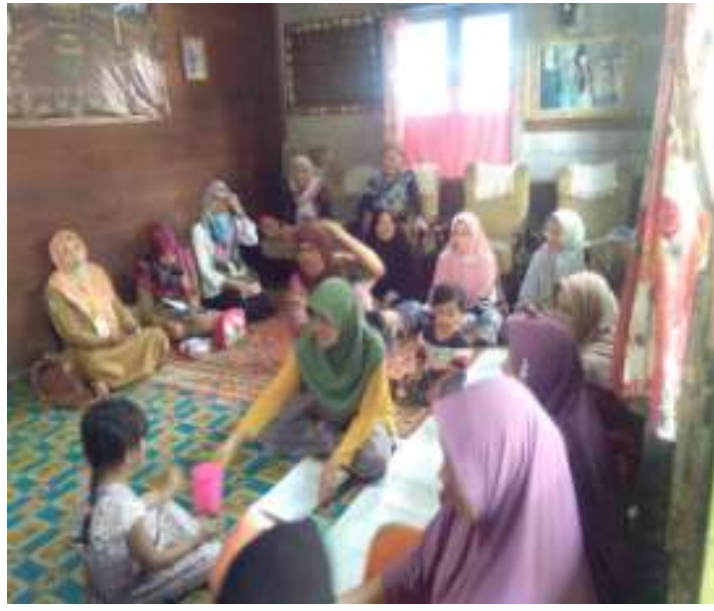

Gambar 2. Kondisi saat penyuluhan berlangsung
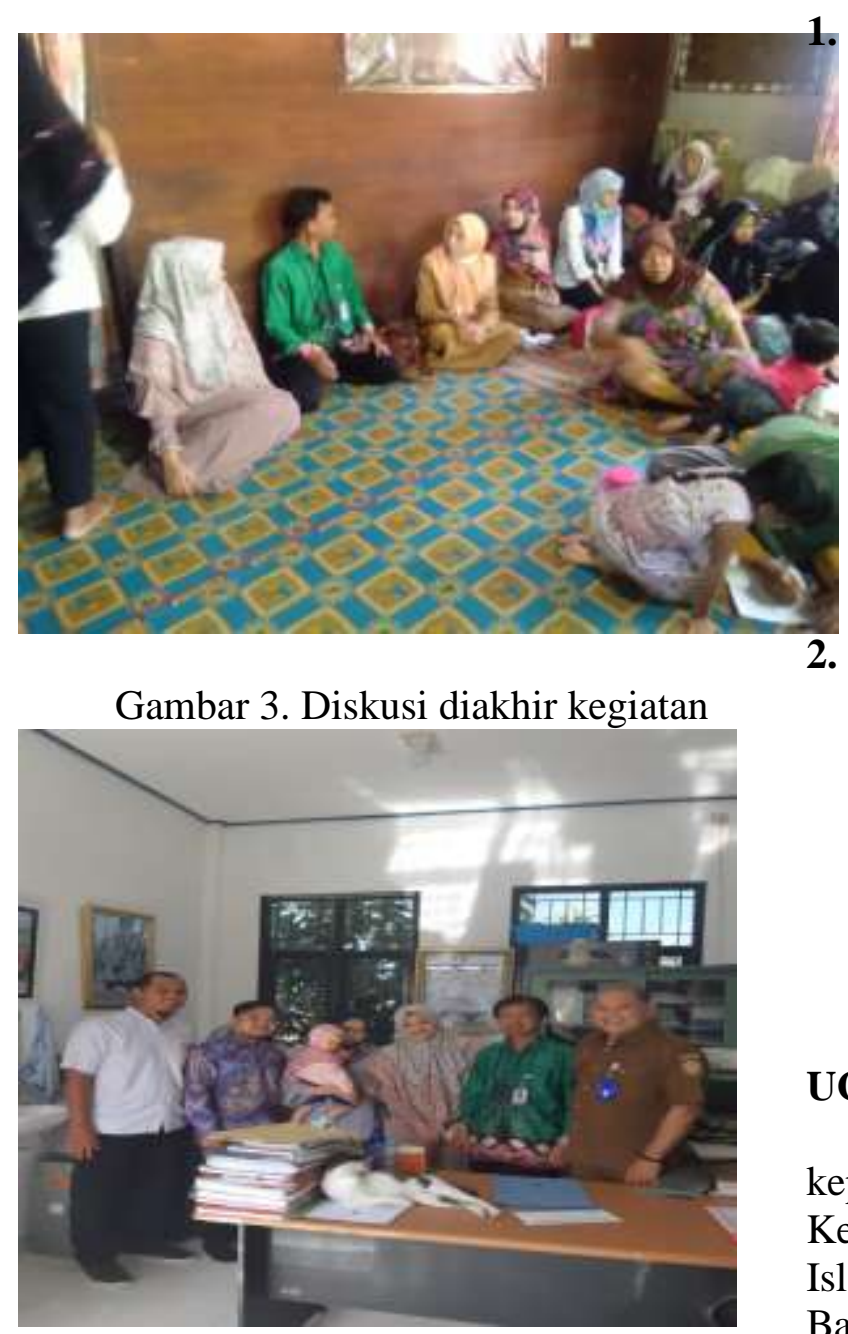

Gambar 4. Foto bersama Tim Pengabdian, Kepala Puskesmas dan Petugas Posbindu
2.

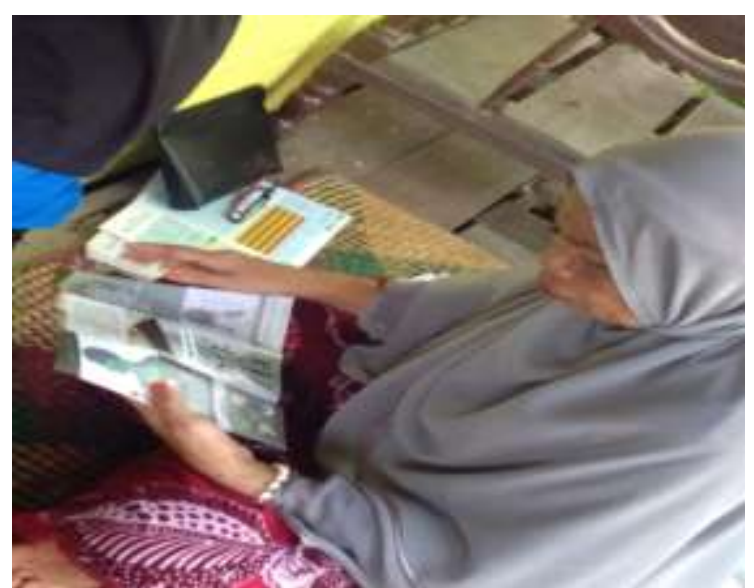

Gambar 5. Salah satu peserta kegiatan

\section{KESIMPULAN DAN SARAN}

\section{Kesimpulan}

Kegiatan pengabdian ini mendapat sambutan yang hangat, baik dari pihak Puskesmas Alalak Tengah maupun masyarakat. Meskipun ada beberapa kendala, kegiatan pengabdian dapat berjalan lancar. Dampak yang tampak dari kegiatan pengabdian antara lain adanya peningkatan pengetahuan masyarakat tentang ispa dan tata cara penggunaan masker serta meningkatnya perilaku penggunaan masker saat melakukan aktifitas di luar rumah.

\section{Saran}

a. Melaksanakan kegiatan sosialisasi kepada masyarakat sebagai tindakan kewaspadaan dini terhadap ISPA.

b. Pelaksanaan kegiatan sosialisasi dapat dilaksanakan secara bertahap mengingat jumlah penduduk yang cukup banyak.

\section{UCAPAN TERIMAKASIH}

Ucapan terima kasih disampaikan kepada Lembaga Penelitian dan Pengabdian Kepada Masyarakat (LPPM) Universitas Islam Kalimantan Muhamaad Arsyad Al Banjari Banjarmasin yang telah membiayai kegiatan ini. Ucpan terima kasih juga disampaikan kepada mitra, Puskesmas Alalak Tengah telah memberikan izin dan 
mendampingi pelaksanaan sehingga dapat berjalan lancar.

\section{DAFTAR PUSTAKA}

Abdi, A.P. 2019 . Kasus ISPA Meningkat Saat Kekeringan dan Karhutla Melanda. https://tirto.id/kasus-ispameningkat-saat-kekeringan-dankarhutla-melanda-egR3. Diakses tanggal 20 September 2019

Amin, M. 2010. Dampak Kebakaran Hutan pada Pernapasan dalam Buku Ajar Ilmu Penyakit Paru. Surabaya: Departemen Ilmu Penyakit Pari Fakultas Kedokteran Universitas Airlangga.

Anonymous. 2019. Di Banjarmasin, 26 Puskesmas Tangani Pasien ISPA Karena Asap. (http://kumparan.com). 20 September 2019

Kemenkes RI.2015. Masalah Kesehatan Akibat Kabut Asap Kebakaran Hutan dan Lahan. Pusat Informasi dan Data Kementrian Kesehatan. Jakarta Selatan

Kemenkes RI. (2017). Rencana Aksi Nasional Pencegahan dan Pengendalian Penyakit Tidak Menular 2015-2019. http://p2ptm.kemkes.go.id/uploads/VH crbkVobjRzUDN3UCs4eUJOdVBndzO 9/2018/10/Buku_Rencana_Aksi_Nasio nal_2015_2019.pdf. Diakses tanggal 20 September 2019

Kembaren, Lidya. (2019). Pak Jokowi, Ratusan Ribu Rakyat Kena ISPA Gegara Karhutla. https://www.cnbcindonesia.com/news/ 20190922111456-4-101250/pakjokowi-ratusan-ribu-rakyat-kenaispa-gegara-karhutla. Diakses tanggal 22 September 2019.

Kunoli, M.F. 2013. Pengantar Epidemiologi Penyakit Mnular. Jakarta : TIM.

Notoadmojo, Soekidjo. (2007).Promosi Kesehatan dan Ilmu Perilaku.Jakarta: Rineka Cipta.
Notoadmojo, Soekidjo. (2007).Promosi Kesehatan; Teori dan Aplikasi. Jakarta: Rineka Cipta.

Pusdatin Kemenkes RI. 2015. Masalah Kesehatan Akibat Kabut Asap Kebakaran Hutan dan Lahan Tahun 2015. Jakarta: Kementrian Kesehatan RI.

Puskesmas Alalak Tengah. 2018. Laporan Tahunan Puskesmas Alalak Tengah. Banjarmasin.

Suni, N.S.P., (2019). Strategi Pengendalian ISPA Akibat Kebakaran Hutan dan Lahan. http://berkas.dpr.go.id/puslit/files/info _singkat/Info\%20Singkat-XI-19-IP3DI-Oktober-2019-1957.pdf. Diakses tanggal 20 Oktober 2019 